\title{
Pelaksanaan Bimbingan Pribadi Sosial Dalam Mengembangkan Keterampilan Sosial Siswa Terisolir Di SMP Negeri 5 Banguntapan
}

\author{
Anisatun Murtafiah \\ IAIN Salatiga, Salatiga, Indonesia \\ anisatunmurtafiah99@gmail.com \\ Octavia Arlina Sahara \\ Universitas Proklamasi 45, Yogyakarta, Indonesia \\ octavia.23oas@gmail
}

\begin{abstract}
Abstrak
Penelitian ini bertujuan untuk mengamati pelaksanaan bimbingan pribadi sosial dalam mengembangkan keterampilan sosial siswa terisolir Di SMP Negeri 5 Banguntapan. Penelitian ini termasuk jenis penelitian lapangan (field research) dengan pendekatan kualitatif. Metode pnggalilian data menggunakan wawancara, observasi dan dokumentasi dengan subjek penelitian guru BK, peserta didik dan orang tua siswa kemudian dianalisis dengan teknik analisis deskriptif. Hasil penelitian menunjukkan bahwa Pelaksanaan bimbingan pribadi sosial dalam mengembangkan keterampilan sosial siswa terisolir di SMP Negeri 5 Banguntapan dilaksanakan dengan beberapa tahapan yaitu 1) Persiapan meliputi menentukan personil, alat assessment dan identifikasi siswa juga kategori siswa terisolir 2) Pelaksanaan meliputi menyusun program dan implementasi program penanganan 3) Evaluasi hasil pelaksanaan dan 4) Tindak lanjut hasil pelaksanaan.
\end{abstract}

Kata kunci: Pribadi Sosial, Keterampilan Sosial, Terisolir

\begin{abstract}
Implementation of Social Personal Guidance in Developing the Social Skills of Isolated Students in SMP Negeri 5 Banguntapan. This study aims to observe the implementation of social personal guidance in developing social skills of isolated students in SMP Negeri 5 Banguntapan. This research is a type of field research with a
\end{abstract}


qualitative approach. Data collection method uses interviews, observations and documentation with the BK teacher's research subjects, students and parents of students then analyzed using descriptive analysis techniques. The results showed that the implementation of social personal guidance in developing social skills of isolated students at SMP Negeri 5 Banguntapan was carried out in several stages, namely 1) Preparation includes determining personnel, assessment tools and student identification as well as the category of isolated students 2) Implementation includes arranging programs and implementing handling programs 3) Evaluation of results of implementation and 4) Follow-up of results of implementation.

Keywords: Social Personal, Social Skills, Isolated

\section{A. Pendahuluan}

Secara kodrati manusia merupakan makhluk sosial (Faqih, 2001: 10). Sehingga setiap manusia memiliki kecenderungan untuk bergaul dengan orang lain, bersahabat, bermasyarakat, dan berkelompok. Sebagaimana disampaikan dalam firman Allah SWT dalam Q.S Al Hujurat ayat 13:

Artinya: "Hai manusia, sesungguhnya Kami menciptakan kamu dari seorang laki-laki dan seorang perempuan dan menjadikan kamu berbangsa-bangsa dan bersuku-suku supaya kamu saling kenal-mengenal. Sesungguhnya orang yang paling mulia di antara kamu di sisi Allah ialah orang yang paling taqwa di antara kamu. Sesungguhnya Allah Maha mengetahui lagi Maha Mengenal."(Depag RI, 2010: 412).

Sebagai makhluk sosial, manusia lahir, hidup dan berkembang dalam lingkungan sosial. Sehingga senantiasa berinteraksi dengan manusia lain karena saling membutuhkan. Dengan demikian setiap manusia harus dapat menyesuaikan diri, baik dalam perilaku, kesopanan bahasa, maupun sikap yang kesemuanya merupakan dasar perubahan (Burhanudin, 1999: 51). Tidak terkecuali siswa sebagai kelompok manusia, karena siswa yang menurut usia perkembangan agamanya, tergolong sebagai remaja juga tidak lepas dari kehidupan sosialnya. Dalam rangka memenuhi kebutuhan hidup sosialnya inilah siswa juga dituntut untuk memiliki keterampilan sosial, agar mampu menyesuaikan diri dengan lingkungan sosial.

Remaja termasuk juga siswa yang dapat menyesuaikan diri dengan lingkungan sosialnya, maka dirinya akan mempelajari berbagai keterampilan sosial seperti kemampuan untuk menjalin hubungan secara baik dengan orang 
lain, baik terhadap teman maupun terhadap orang yang tidak dikenal, sehingga sikapnya terhadap orang lain menjadi menyenangkan (Hurlock, 1990: 285).

Keterampilan sosial yang harus dimiliki siswa tidak hanya ditunjuk agar perasaannya menyenangkan dan dapat selaras dengan lingkungan sosialnya, tetapi juga dalam rangka pengembangan dirinya menuju kedewasaan. Di samping juga untuk menunjang kesehatan dan juga kesejahteraan psikologisnya dalam mengarungi kehidupan ke depan. Oleh sebab itu keterampilan sosial penting untuk dimiliki oleh setiap siswa. Sebagaimana yang dikatakan oleh Johnson \& Johnson bahwa individu yang memiliki keterampilan sosial akan mampu mengembangkan aspek-aspek psikologisnya; seperti (1) kepribadian dan identitas. (2) kemampuan kerja, produktivitas dan kesuksesan karir. (3) kualitas hidup. (4) kesehatan fisik. (5) kesehatan psikologis. (6) menghadapi stress (Johnson \& Johnson, 1989).

Hasil penelitian menunjukkan bahwa keterampilan sosial dapat membawa remaja untuk lebih berani berbicara, mengungkapkan setiap perasaan atau permasalahan yang dihadapi dan sekaligus menemukan penyelesaian yang adaptif, sehingga mereka tidak mencari pelarian ke hal-hal lain yang justru dapat merugikan diri sendiri maupun orang lain (Anggraeni, 2008).

Setelah memahami pentingnya seseorang memiliki ketetrampilan sosial, selanjutnya memahami pentingnya seseorang dalam menghadapi lingkungan sosial yang termasuk juga salah satu keterampilan sosial. Cara menghadapi lingkungan sosial yang baru dalam kehidupan remaja termasuk juga siswa sangatlah berbeda-beda. Ada yang mampu bergaul dengan harmonis artinya tidak menemukan hambatan-hambatan yang berarti, namun ada pula yang menemukan hambatan dalam bergaul. Misalnya, siswa yang mempunyai masalah pertemanan di sekolah, maka siswa yang seperti ini benar-benar tidak disukai dari kelompok teman-temannya dan dirinya tergolong siswa terisolasi (Knoers \& Haditono, 2004: 276).

Begitu juga sebaliknya, siswa yang tidak memiliki keterampilan sosial akan kesulitan dalam menjadi dan mengembangkan serta berinteraksi dengan lingkungan sosial. Kondisi ini banyak ditemukan fenomena-fenomena dalam kehidupan sehari-hari. Misalnya ketika di dalam kelas siswa tersebut duduk di pojok paling belakang, suka menyendiri dan cenderung pendiam, sulit memiliki pembawaan, apalagi berkomunikasi dengan lawan jenis, dan masih banyak lagi contoh perilaku menarik diri siswa yang tidak memiliki keterampilan sosial. 
Siswa yang status usianya masih remaja secara sosial perkembangannya memiliki dua arah gerak, yakni memisahkan diri dengan orang tua dan gerak menuju ke arah teman-teman sebayanya. Kedua jenis gerak sosial ini saling berurutan dan terkait erat, sehingga jika gerak pertama dilakukan dan gerak kedua tidak, maka siswa tersebut menjadi atau tergolong siswa terasing (Knoers \& Haditono, 2004: 277).

Siswa yang terisolasi akan menjadi pribadi yang tidak matang secara sosial, emosional dan spiritual. Siswa tersebut akan memiliki kepribadian yang terganggu akibat kehilangan kasih sayang dan cinta dari lingkungan sosialnya, sehingga dirinya akan menjadi pribadi anti sosial. Akibatnya siswa yang bersangkutan tidak bisa mengembangkan hubungan yang harmonis dengan orang lain (Safira, 2005: 39).

Siswa yang terisolasi secara sosial akan menunjukkan gejala-gejala yang tidak sehat. Gejala ini merupakan suatu penyakit sosial yang biasa disebut rasa malu. Akibat jangka panjang dari rasa malu yang berlebihan ini, akan memunculkan penyakit sosial seperti kesepian, rendah diri, menarik diri, penilaian sosial yang kurang baik, bahkan dikatakan sebagai individu yang tidak ramah (Safira, 2005: 13).

Siswa yang dikucilkan (tidak disukai) memiliki karakteristik negatif seperti suka menyerang, agresif, bertindak anti sosial, sulit bekerja sama, ingin menyerang sendiri, sulit berempati dan selalu mengganggu kesenangan temannya. Sementara siswa yang disukai (populer) lebih memiliki karakteristik positif seperti mereka suka menolong, perhatian, baik hati, mau bekerjasama, mudah memahami perasaan orang lain, dan lebih cakap dalam memulai/ mempertahankan interaksi sosialnya (vidaiponk.blogspot.com, 2012).

Isi dalam UU Depdiknas RI No. 20 Tahun 2013 yaitu pemenuhan kebutuhan siswa untuk saling bergaul sesama teman, guru merupakan salah satu kebutuhan siswa untuk bersosialisasi dan bergaul. Dalam masalah ini, sekolah adalah lembaga yang dianggap penting dalam memainkan perannya sebagai tempat belajar bagi siswa, bergaul dan beradaptasi dengan lingkungannya. Dengan demikian sekolah tidak hanya berperan sebagai transformer ilmu pengetahuan, tetapi sekolah juga berperan dalam mengembangkan potensi diri siswa untuk memiliki kekuatan spiritual keagamaan, pengendalian diri, kepribadian, kecerdasan, akhlak, mulia serta keterampilan yang diperlukan dirinya, masyarakat, bangsa dan negara (Zikra, 2013). 
Dari hasil observasi yang dilakukan sebelum penelitian, ditemukan adanya masalah yang dialami oleh siswa di SMP Negeri 5 Banguntapan yaitu kurangnya keterampilan sosial yang dimiliki oleh siswa sehingga siswa tersebut menjadi terisolir. Hasil observasi ini juga dikuatkan dengan data yang dimiliki oleh guru BK bahwa pada tahun ajaran 2013/2014 terdapat siswa terisolir yang meningkat di banding tahun ajaran sebelumnya. Pada tahun ajaran 2013/2014 terdapat 21 siswa terisolir padahal tahun ajaran sebelumnya hanya terdapat 5 sampai 10 siswa. Salah satu penyebab keterisoliran siswa ini yaitu kurangnya keterampilan sosial yang dimiliki.

Sejalan dengan adanya masalah keterampilan sosial siswa terisolir yang dihadapi oleh siswa SMP Negeri 5 Banguntapan, maka diperlukan upaya guru BK dalam membantu mengembangkan keterampilan sosial pada siswa terisolir. Dalam usaha menyejahterakan para siswa terutama siswa yang mengalami keterisoliran, maka sekolah memberikan layanan bimbingan dan konseling kepada siswa. Hal ini jelas bahwa bimbingan dan konseling turut memiliki andil dalam membantu memecahkan masalah atau hambatan siswa dalam proses penyesuain sosial di sekolah yang akan sangat berkaitan erat dengan faktor-faktor yang mempengaruhinya. Salah satu faktor yang dapat berpengaruh kuat terhadap proses penyesuain sosial siswa adalah keterampilan sosial (Siswati, 2010).

Salah satu bidang bimbingan yang dapat mengarahkan remaja menuju pada kemampuan penyesuaian sosial adalah bimbingan pribadi sosial. Melalui bimbingan pribadi sosial ini siswa akan diberi pemahaman dari berbagai informasi yang berkaitan dengan bidang sosial, terutama mengenai kemampuan penyesuaian sosial remaja misalnya masalah pergaulan antar remaja dan cara pengendaliannya, hak dan kewajiban sebagai anggota sekolah dan masyarakat serta etika pergaulan antar pria dan wanita (Rahman, 2003: 48).

Di sinilah peran guru BK dalam membantu peserta didik untuk mengembangkan keterampilan sosialnya agar siswa yang terisolir dapat menjadi pribadi yang mantap, mandiri serta mampu mengoptimalkan potensi yang dimiliki dan dapat bersosialisasi dengan baik, sehingga siswa tersebut dapat menjalankan kehidupannya seperti siswa yang lain. Dari pemaparan tersebut menjadi menarik bagi peneliti untuk melakukan penelitian terkait pelaksanaan dan metode bimbingan pribadi sosial yang dilakukan guru BK untuk membantu peserta didiknya dalam mengembangkan keterampilan sosial yang pada penelitian ini adalah siswa terisolir. 


\section{B. Pembahasan}

Berisi (1) teori-teori yang relevan dengan penelitian. Sajikan kajian teori dengan font Cambria (Headings) ukuran 12pt. (2) Metode/rancangan penelitian, populasi dan sampel, instrumen, validitas dan realibilitas instrumen, dan cara analisis data, (3) Hasil penelitian menggambarkan temuan utama dari penelitian. Penulis menyusun, menganalisis, mengevaluasi dan menginterpretasi serta membandingkan hasil temuan terbaru dengan temuan dari penelitian yang telah ada. Hindari pengulangan kalimat baik dari pendahuluan, metode maupun hasil. Jumlah paragraf pembahasan sebaiknya lebih panjang dari pendahuluan. Konsistensi artikel mulai dari judul hingga pembahasan harus diperhatikan. Kelemahan penelitian dan saran untuk pengembangan penelitian selanjutnya dijabarkan pada bagian ini.

Pembahasan ditulis dengan dengan jarak 1,5 spasi dan ditebalkan. Sajian dalam pembahasan ditulis secara bersistem dengan menggunakan format sub bahasan angka dan huruf. Jika terdapat gambar/ tabel maka pastikan memuat data/informasi yang terkait dengan tujuan penelitian. Tabel dan gambar dimasukkan dalam badan naskah. Judul tabel dan gambar diberi penomoran dan ditulis dengan huruf Cambria (Headings) font 12, spasi 1. Untuk gambar sebaiknya menggunakan ukuran pixel 300 untuk ketajaman dan kualitas gambar yang optimal (diupayakan dalam format JPG).

\section{Bimbingan Konseling Pribadi-sosial}

Bimbingan menurut Tohirin adalah bantuan yang diberikan oleh pembimbing kepada individu agar individu yang dibimbing mencapai kemandirian dengan mempergunakan berbagai bahan, melalui interaksi, dan pemberian nasihat serta gagasan dalam suasana asuhan dan berdasarkan norma-norma yang berlaku (Tohirin, 2017: 20). Sementara Bimo Walgito menjelaskan bimbingan adalah bantuan atau pertolongan yang diberikan kepada individu atau sekumpulan individu untuk menghindari atau mengatasi kesulitan-kesulitan di dalam kehidupannya sehingga individu atau sekumpulan individu itu dapat mencapai kesejahteraan hidupnya (Walgito, 2004: 7).

Kedua pemaparan terkait makna bimbingan di atas dapat disimpulkan bahwa bimbingan adalah suatu bantuan yang diberikan oleh pembimbing kepada individu atau sekumpulan individu berupa nasihat atau arahan yang sesuai dengan norma-norma yang berlaku agar individu atau sekumpulan individu tersebut 
memiliki kemandirian dalam perkembangan yang optimal dan mencapai kesejahteraan hidupnya.

Adapun pengertian bimbingan pribadi sosial menurut beberapa ahli adalah sebagai berikut:

Menurut Bimo Walgito:

Bimbingan pribadi sosial adalah upaya dalam membantu siswa mengembangkan sikap, jiwa dan tingkah laku pribadi dalam kehidupan kemasyarakatan dari lingkungan yang besar (Negara dan masyarakat dunia), berdasarkan ketentuan yang menjadi landasan bimbingan dan penyuluhan yakni dasar negara, haluan negara, tujuan negara dan tujuan pendidikan nasional (Walgito, 1989: 49).

Pengertian di atas menekankan pentingnya bimbingan pribadi sosial agar siswa mampu bertahan dalam kehidupan bermasyarakat yang luas.

Menurut Dewa Ketut Sukardi:

Bimbingan Pribadi Sosial merupakan usaha bimbingan dalam menghadapi dan memecahkan masalah pribadi sosial, seperti penyesuaian diri, menghadapi konflik dan pergaulan (Sukardi, 1993: 11).

Sedangkan menurut Abu Ahmadi yang dimaksud dengan bimbingan pribadi sosial adalah:

Seperangkat bantuan kepada peserta didik agar dapat menghadapi sendiri masalah-masalah pribadi dan sosial, memilih kelompok sosial dan kegiatan rekreatif yang bernilai guna, serta berdaya upaya sendiri dalam memecahkan masalah-masalah pribadi, rekreasi dan sosial yang dialaminya (Ahmadi \& Rohani, 1991: 109).

Mengacu pada pendapat berbagai ahli di atas dapat dinyatakan bahwa bimbingan pribadi sosial merupakan usaha bimbingan dalam membantu menghadapi dan menyelesaikan masalah pribadi sosial, seperti penyesuaian diri, menghadapi konflik dan pergaulan.

Syamsu Yusuf, secara rinci menyebutkan tujuan yang ingin dicapai dari bimbingan pribadi sosial antara lain:

a. Memiliki komitmen yang kuat dalam mengamalkan nilai-nilai keimanan dan ketakwaan kepada Tuhan Yang Maha Esa, baik dalam kehidupan pribadi, 
keluarga, pergaulan dengan teman sebaya, sekolah, tempat kerja, maupun masyarakat pada umunya.

b. Memiliki sikap toleransi terhadap umat beragama lain, dengan saling menghormati dan memelihara hak dan kewajibannya masing-masing.

c. Memiliki pemahaman tentang irama kehidupan yang bersifat fluktuatif antara yang menyenangkan (anugrah) dan yang tidak menyenangkan (musibah), serta mampu meresponnya secara positif sesuai dengan ajaran agama yang dianut.

d. Memiliki pemahaman dan penerimaan diri secara objektif dan konstruktif, baik yang terkait dengan keunggulan maupun kelemahan baik fisik maupun psikis.

e. Memiliki sikap positif atau respek terhadap diri sendiri dan orang lain.

f. Memiliki kemampuan melakukan pilihan secara sehat.

g. Bersikap respek terhadap orang lain, menghormati atau menghargai orang lain, tidak melecehkan martabat atau harga dirinya.

h. Memiliki rasa tanggung jawab, yang diwujudkan dalam bentuk komitmen terhadap tugas dan kewajibannya.

i. Memiliki kemampuan berinteraksi sosial (human relationship), yang diwujudkan dalam bentuk persahabatan, persaudaraan, atau silaturahim dengan sesama manusia.

j. Memiliki kemampuan dalam menyelesaikam konflik (masalah) baik bersifat internal (dalam diri sendiri) maupun dengan orang lain.

k. Memiliki kemampuan untuk mengambil keputusan secara efektif (Yusuf, 2006: 14).

Berdasarkan pemaparan di atas, diketahui bahwa tujuan dari layanan bimbingan pribadi sosial adalah membantu siswa untuk dapat mengamalkan nilainilai keimanan dan ketaqwaan terhadap Tuhan Yang Maha Esa, mampu memahami dan menerima kelebihan dan kekurangan diri sendiri, bersikap respek terhadap sesama dan diri sendiri, mengambil keputusan secara efektif, memiliki rasa tanggung jawab, memiliki kemampuan berinteraksi sosial dan dapat menyelesaikan konflik pribadi maupun sosial.

Sedangkan menurut Dewa Ketut Sukardi, tujuan dari bimbingan pribadi sosial adalah untuk membantu siswa agar: 
a. Memiliki kesadaran diri, yaitu menggambarkan penampilan dan mengenal kekhususan yang ada pada dirinya. Siswa diarahkan untuk lebih dapat mengenali dirinya sendiri, jadi setelah siswa dapat mengenali dirinya sendiri maka siswa tersebut dapat mengetahui potensi yang dimiliki dan akan dibawa kemana setelah mengetahuinya.

b. Dapat mengembangkan sikap positif, seperti menggambarkan orang-orang yang mereka senangi. Berpikir positif akan membawa dampak yang baik, setidaknya berpikiran positif merupakan sebuah sugesti. Cara yang paling mudah dilakukan bagi siswa salah satunya dengan memberi gambaran tentang orang-orang yang mereka senangi.

c. Membuat pilihan secara sehat. Salah satu tujuan dari bimbingan pribadi sosial yang dapat membantu siswa adalah membuat pilihan secara sehat oleh siswa itu sendiri, jadi ketika siswa dihadapkan dengan beberapa pilihan khususnya yang berhubungan dengan cara siswa tersebut bersosialisasi maka siswa tersebut secara bijak dapat menentukan. Sebagai contoh; bersosialisasi ada yang positif dan ada pula yang negatif. Bersosialisasi negatif seperti geng motor. Dan bersosialisasi positif seperti ikut kegiatan OSIS dan belajar kelompok.

d. Mampu menghargai orang lain. Sikap menghargai harus tertanan dalam setiap individu, karena setiap individu pasti ingin selalu dihargai. Jadi dalam hal ini siswa dituntut untuk dapat menghargai orang lain sebelum ingin dihargai.

e. Memiliki rasa tanggung jawab. Rasa tanggung jawab sangat perlu ditanamkan bagi siswa dalam bimbingan pribadi sosial, karena individu yang memiliki rasa tanggung jawab sangat dibutuhkan dalam bersosialisasi.

f. Mengembangkan keterampilan hubungan antar pribadi. Dengan adanya bimbingan pribadi sosial mengembangkan keterampilan hubungan antar pribadi perlu diupayakan, karena interaksi sosial yang paling terkecil adalah antar individu.

g. Dapat menyelesaikan konflik. Tujuan berikutnya dari sebuah bimbingan pribadi sosial adalah agar siswa dapat menyelesaikan konflik yang sedang terjadi entah itu yang terdapat dalam dirinya sendiri ataupun konflik yang ada diluar individu siswa tersebut.

h. Dapat membuat keputusan secara efektif. Seperti halnya poin nomor tiga, tujuan dari bimbingan pribadi sosial harus dapat membuat siswa yang 
memiliki keterampilan sosial yang kurang dapat membuat keputusan secara efektif dengan beberapa pertimbangan yang dimilikinya (Sukardi, 1993: 29).

Inti dari kedua pendapat ahli akan tujuan yang ingin dicapai dari bimbingan pribadi sosial adalah membantu individu atau siswa agar mampu menerima dan dan memahami dirinya sendiri serta lingkungan sekitarnya, sehingga siswa dapat menyelesaikan permasalahan pribadi dan sosial yang dihadapinya.

Berikut ini konsep metode bimbingan dan konseling menurut Ainur Rahim Faqih yang dapat dijadikan rujukan dalam menjelaskan metode bimbingan pribadi sosial, karena bimbingan pribadi sosial merupakan bagian/bidang dari bimbingan dan konseling. Konsep tersebut adalah:

a. Metode Langsung adalah metode dimana pembimbing melakukan komunikasi langsung atau bertatap muka dengan orang yang dibimbingnya. Metode ini dapat dirinci lagi meliputi:

1) Metode Individual adalah melakukan komunikasi langsung secara individual dengan pihak yang dibimbing. Adapun teknik yang digunakan yaitu: (1) Percakapan pribadi, yaitu pembimbing melakukan dialog langsung secara tatap muka dengan pihak yang dibimbing. (2) Kunjungan rumah (home visit), yaitu pembimbing mengadakan dialog dengan kliennya dan orang tuanya tetapi dilaksanakan di rumah klien sekaligus untuk mengamati keadaan rumah klien dan kehidupan sosial klien di lingkungan rumah.

2) Metode Kelompok adalah melakukan komunikasi langsung secara berkelompok dan dapat dilakukan dengan teknik-teknik sebagai berikut; (1) Diskusi kelompok, yaitu pembimbing melaksanakan bimbingan dengan cara mengadakan diskusi dengan kelompok klien yang mempunyai masalah yang sama. (2) Karya wisata, yaitu bimbingan atau konseling yang dilakukan secara langsung dengan mempergunakan ajang karya wisata sebagai forumnya. (3) Sosiodrama, yaitu bimbingan pribadi yang dilakukan dengan cara bermain peran untuk memecahkan atau mencegah timbulnya masalah. (4) Group teaching, yaitu pemberian bimbingan dengan memberikan materi yang sesuai dengan topik bimbingan kepada kelompok yang telah disiapkan.

b. Metode Tidak Langsung adalah metode bimbingan yang dilakukan melalui media massa dan dapat dilakukan secara individual maupun kelompok. Metode individual meliputi surat menyurat dan telepon, sedangkan metode 
kelompok meliputi papan bimbingan, surat kabar atau majalah, brosur, radio, dan televisi.

Metode dan teknik yang digunakan dalam melaksanakan bimbingan dan konseling tergantung pada masalah yang dihadapi, tujuan penyelesaian masalah, keadaan yang dibimbing/ klien, kemampuan pembimbing/ konselor mempergunakan metode dan teknik, sarana dan prasarana yang tersedia, kondisi dan situasi sekitar, organisasi dan administrasi layanan bimbingan dan konseling, serta biaya yang tersedia (Latipun, 2001: 231).

\section{Keterampilan sosial}

Adapun pengertian keterampilan menurut beberapa ahli adalah sebagai berikut:

Menurut Kelly J.A: "Social skills (social skill) as learned behaviors, which are used by individuals in interpersonal situations in the environment." Keterampilan sosial (social skill) sebagai perilaku-perilaku yang dipelajari, yang digunakan oleh individu pada situasi-situasi interpersonal dalam lingkungan (Kelly, 1982: 49).

Menurut Peterson L:

"Keterampilan sosial adalah kemampuan berkomunikasi, menjalin hubungan dengan orang lain, menghargai diri sendiri dan orang lain, mendengarkan pendapat atau keluhan dari orang lain, memberi atau menerima feedback, memberi atau menerima kritik, bertindak sesuai norma dan aturan yang berlaku, dan lain sebagainya (Petersen, 2004: 36)."

Sedangkan Mu'tadin mengemukakan bahwa salah satu tugas perkembangan yang harus dikuasai remaja yang berada dalam fase perkembangan masa remaja madya dan remaja akhir adalah memiliki ketrampilan sosial (social skill) untuk dapat menyesuaikan diri dengan kehidupan sehari-hari. Keterampilanketerampilan sosial tersebut meliputi kemampuan berkomunikasi, menjalin hubungan dengan orang lain, menghargai diri sendiri dan orang lain, mendengarkan pendapat atau keluhan dari orang lain, memberi atau menerima feedback, memberi atau menerima kritik, bertindak sesuai norma dan aturan yang berlaku. Apabila keterampilan sosial dapat dikuasai oleh remaja pada fase tersebut maka akan mampu menyesuaikan diri dengan lingkungan sosialnya (Mu'tadin,2013).

Mengacu pada pendapat berbagai ahli di atas dapat dinyatakan adalah kemampuan individu untuk berkomunikasi efektif dengan orang lain baik secara 
verbal maupun nonverbal sesuai dengan situasi dan kondisi yang ada pada saat itu. Keterampilan ini merupakan perilaku yang dipelajari. Remaja dengan keterampilan sosial akan mampu mengungkapkan perasaan baik positif maupun negatif dalam hubungan interpersonal, tanpa harus melukai orang lain.

\section{Faktor-faktor yang Mempengaruhi Keterampilan Sosial}

Sebagai kemampuan yang diperoleh melalui proses belajar, maka perkembangan sosial siswa tergantung pada berbagai faktor, yaitu kondisi anak sendiri serta pengalaman interaksinya dengan lingkungan sebagai sarana dan media pembelajaran. Menurut beberapa ahli faktor-faktor tersebut adalah sebagai berikut:

a. Faktor internal

Menurut Kagan Bates beberapa kondisi yang mempengaruhi tingkat keterampilan sosial individu (termasuk siswa), antara lain: (1) Temperamen, Individu yang memiliki temperamen sulit dan cenderung mudah terluka secara psikis, biasanya akan takut atau malu-malu dalam mengadapi stimulus sosial yang baru, sedangkan individu yang ramah dan terbuka lebih responsive terhadap lingkungan sosial. Selain itu individu yang memiliki temperamen, cenderung lebih agresif dan impulsive, sehingga sering ditolak oleh teman sebaya. Kedua kondisi ini menyebabkan kesempatan mereka untuk berinteraksi dengan teman sebaya kurang, padahal interaksi mereka merupakan media yang penting dalam proses belajar keterampilan sosial (Siswati, 2010). (2) Regulasi emosi, kemampuan mengatur emosi juga mempengaruhi keterampilan sosial individu. Pengaturan emosi sangat membantu, baik bagi aindividu yang mampu bersosialisasi dengan lancar maupun yang tidak. Individu yang mampu bersosialisasi dan mengatur emosi akan memiliki keterampilan sosial yang baik sehingga kompetensi sosialnya juga tinggi. Individu yang kurang mampu bersosialisasi namun mampu mengatur emosi, maka walaupun jaringan sosialnya tidak luas tetapi dia tetap mampu berteman secara konstruktif dan berani bereksplorasi saat bermain sendiri. Sedangkan individu yang mampu bersosialisasi namun kurang dapat mengontrol emosi, cenderung berperilaku agresif dan merusak. Adapun individu yang tidak mampu bersosialiasi dan mengontrol emosi cenderung lebih pencemas dan kurang berani bereksplorasi (Siswati, 2010). (3) Kemampuan sosial kognitif, Perkembangan keterampilan sosial individu juga dipengaruhi oleh kemampuan sosial kognitif yaitu kemampuan memproses semua informasi yang ada dalam proses sosial. Kemampuan ini antara lain 
kemampuan mengenali isyarat sosial, menginterpretasi isyarat sosial dengan cara yang tepat dan bermakna, mengevaluasi konsekuensi dari beberapa kemungkinan respon serta memilih respon yang akan dilakukan. Kemampuan sosial kognitif lainnya yang juga penting adalah kemampuan melihat perspektif orang lain (perspektif talking) dan kemampuan empati. Semakin baik keterampilan memproses informasi sosial anak, maka akan semakin mudah baginya untuk membentuk hubungan suportif dengan orang lain, yang berarti akan menambah luas jaringan sosial sebagai media pengembangan keterampilan sosial (Siswati, 2010).

b. Faktor eksternal

Menurut Rubin Bukowsky dan Parker secara umum pola interaksi sosial anak dan orang tua serta kualitas hubungan pertemanan dan penerimaan anak dalam kelompok merupakan dua faktor eksternal atau lingkungan yang cukup berpengaruh bagi perkembangan sosial anak. Anak banyak belajar mengembangkan keterampilan sosial baik dengan proses modelling (mencontoh) terhadap perilaku orang tua dan teman sebaya, ataupun melalui penerimaan penghargaan saat melakukan sesuatu yang tepat dan penerimaan hukuman saat melakukan sesuatu yang tidak pantas menurut orang tua dan teman sebaya (Siswati, 2010).

Berdasarkan pemaparan di atas dapat disimpulkan bahwa secara umum keterampilan sosial dipengaruhi oleh dua yakni faktor internal yang berasal dari dalam individu berupa temperamen, regulasi emosi, dan kemampuan sosial kognitif, kemudian faktor eksternal yang berasal dari luar diri individu meliputi lingkungan keluarga dan teman sebaya.

Menurut Stephen N. Elliott, PhD, Professor Vanderbilt University Nashville, menyebutkan tujuh (7) karakteristik siswa yang memiliki keterampilan sosial, antara lain: (1) Mampu berkomunikasi efektif, Kemampuan komunikasi diantaranya adalah kemampuan bergantian bicara dalam sebuah sesi percakapan. Siswa wajib diajarakan untuk sabar mendengarkan orang bicara tidak boleh menyela sampai pembicara menyelesaikan pembicaraannya. Sehingga siswa terbiasa menghormati orang lain dan mampu menjadi pendengar yang baik. Setelah lawan bicara selesai berbicara barulah kita memeberi tanggapan sehingga tidak akan timbul kegaduhan dalam pembicaraan. Selain itu kemampuan membuat kontak mata dengan lawan bicara juga sangat penting untuk dipelajari. Karena kontak mata itu bisa menandakan penghormatan dan keseriusan orang yang lagi berbicara. Tanpa kontak mata yang benar pembicaraan akan menjadi hambar dan 
interaksipun bisa bubar. (2) Mampu bekerjasama dengan baik, Kemampuan bekerjasama adalah kemampuan mengkompromikan kepentingan pribadi dengan kepentingan orang lain. Selain itu kemampuan bekerjasama juga berarti kemampuan untuk mengedalikan diri untuk tidak melanggar peraturan yang berlaku atau diberlakukan, karena kemampuan bekerjasama itu meniadakan penghianatan dengan rekan kerja. (3) Memiliki sikap tegas, Walau siswa diajarkan untuk bekerjasama dengan pihak lain, yang dalam hal ini berarti harus mengkompromikan kepentingan dan kebutuhan bersama. Namun siswa harus diajarkan sikap yang tidak kompromis dan permisif. Siswa harus pula diajari kapan mereka harus tegas bersikap. Serta diajarkan untuk berani mempertanyakan ketidakadilan bila diperlukan. Tanpa sikap ini siswa akan berlari pada kondisi mudah dipermainkan dan ditipu orang lain. Oleh karena itu ketegasan sikap sangat diperlukan dan diajarkan dalam rangka pengajaran keterampilan sosial. (4) Mempunyai tanggung jawab, sikap tanggung jawab siswa bisa diajarkan dengan pengajaran untuk menghormati dan menjaga properti orang lain. Selain itu mengajarkan sikap kestria untuk berani mengakui dan mempertanggungjawabkan perbuatan pribadi juga diperlukan untuk mempertajam sikap dan rasa tanggung jawab siswa siswi kita. (5) Memiliki keterampilan berempati, keterampilan berempati terdiri dari kamampuan untuk bisa ikut merasakan penderitaan, kesusahan, kesulitan dan juga kebahagian orang lain. Siswa wajib diajarkan untuk bersikap yang tepat saat menghadapi orang lain yang dalam kondisi psikologis seperti itu. Keterampilan berempati ini kalau sudah tertanam pada diri siswa mereka akan merasa buruk kalau tidak bisa menunjukkan sikap yang tepat saat temannya sedang dalam kondisi bersedih. (6) Terampil bergaul atau melibatkan diri dalam kelompok, keterampilan ini akan ditandai kemampuan siswa mencari teman dengan mudah. Mereka bisa diterima setiap orang, bisa masuk di segala kelompok. Selain masuk dalam lingkaran kelompok tertentu kemampuan siswa juga harus dikembangkan untuk mampu mengundang orang lain masuk dalam kelompoknya atau mengundang orang lain untuk bersahabat dengan mereka. (7) Memiliki kemampuan untuk dapat mengontrol diri, kemampuan kontrol diri perlu diajarkan pada siswa siswi kita agar mereka mampu berkompromi untuk meredam konflik atau mampu mencari pemecahan permasalahan yang berhubungan dengan pihak lain tanpa konflik terbuka. Lebih mantap lagi adalah siswa mampu tetap tenang pada saat mereka digoda, diremehkan atau dicaci maki (Elliott, 1999).

Sedangkan menurut Eisler siswa yang memiliki keterampilan sosial adalah siswa yang berani berbicara, memberi pertimbangan yang mendalam, memberikan 
respon yang lebih cepat, memberikan jawaban yang secara lengkap, mengutarakan bukti-bukti yang dapat meyakinkan orang lain, tidak mudah menyerah, menuntut hubungan timbal balik, serta lebih terbuka dalam mengekspresikan dirinya (Abate \& Milan, 1985).

Berdasarkan pemaparan para ahli di atas kerakteristik siswa yang memiliki keterampilan sosial itu adalah mereka yang mempunyai kemampuan berkomunikasi, kemampuan bekerjasama, sikap tegas, tanggung jawab, keterampilan berempati, keterampilan bergaul atau melibatkan diri dalam suatu kumpulan sosial, kemampuan kontrol diri, menuntut hubungan timbal balik, dan lebih terbuka dalam mengekspresikan dirinya.

\section{Siswa Terisolir}

Berbagai gejala yang muncul di lapangan, permasalahan yang terkait dengan masalah penyesuaian sosial dan pergaulan siswa yang terisolir, antara lain adalah hubungan sosial yang kurang harmonis, kehadiran dalam belajar tidak cukup, sikap dan kebiasaan belajar tidak baik, latar belakang keluarga yang kurang mendukung, konsep diri yang salah, seingga menyebabkan rasa percaya diri kurang, menganggap dirinya bodoh, sarana dan prasarana belajar yang dimiliki minim, tidak memiliki minat belajar, belum mendapatkan pelayanan yang optimal dari guru bimbingan dan konseling (guru BK) (Zikra, 2013).

Menurut Andi Mappiare menyatakan bahwa siswa terisolir adalah siswa yang jarang dipilih atau sering kali mendapat penolakan dari lingkungannya. 1 Siswa terisolir juga merupakan siswa yang tidak mempunyai sahabat, jarang dipilih, selalu ditolak di antara teman sebayanya, tidak mempunyai minat untuk mengikuti kegiatan-kegiatan kelompok, tidak dapat menyerap dan menerima norma-norma ke dalam kepribadiannya, tidak mampu untuk berperilaku yang pantas atau menyesuaikan diri menurut tuntutan ligkungan yang ada, siswa yang jarang dipilih atau sering kali mendapat penolakan dari lingkungannya (Mappiere, 1982: 172-173).

Sedangkan indikator siswa terisolir menurut Elizabeth B. Hurlock adalah: (1) Penampilan diri yang kurang menarik, penampilan diri yang kurang menarik sangat berpengaruh dalam bersosialisasi, karena dalam bersosialisasi hal pertama yang diperhatikan adalah kontak mata. Siswa yang kurang rapi dalam berpenampilan termasuk pemakaian seragam misalnya seragam atas yang 1982), hlm.

${ }^{1}$ Andi Mappiere, Pengantar Bimbingan dan Konseling di Sekolah, (Surabaya: Usaha Nasional, 
dikeluarkan dan memakai seragam yang tidak sesuai dengan jadwal dapat menarik perhatian yang bersifat negaif. (2) Kurang sportif, Siswa yang kurang sportif dalam bersosialisasi ataupun bergaul dapat dijauhi dari teman-temannya. Karena sifat kurang sportif menandakan kurangnya rasa tanggung jawab. (3) Penampilan yang tidak sesuai dengan standar teman, Seperti halnya pada poin pertama, penampilan yang tidak sesuai dengan standar teman merupakan salah satu indikator siswa tersebut dapat dijauhi teman-temannya. Penampilan yang menonjolkan diri, mengganggu orang lain, suka memerintah, tidak bekerjasama dan kurang bijaksana. (4) Mementingkan diri sendiri dan mudah marah. Dalam bersosialisasi mementingkan diri sendiri atau egois dan mudah marah merupakan sifat yang harus dihindari, dengan adanya sifat tersebut rasa kebersamaan akan hilang (Hurlock, 1990: 217).

Berdasarkan pemaparan di atas bahwa indikator siswa terisolir adalah siswa yang berpenampilan kurang menarik, kurang sportif, penampilan tidak sesuai dengan standar teman, penampilan yang menonjolkan diri, dan mementingkan diri sendiri.

Andi Mappiare menyatakan bahwa keterkaitan dengan penerimaan dan penolakan sosial mengemukakan beberapa hal yang menyebabkan seorang remaja diterima atau ditolak dalam kelompoknya, adapun faktor-faktor yang menyebabkan diterima dalam kelompoknya yang dimaksud adalah sebagai berikut: (1) Penampilan (performance) dan perbuatan yang meliputi tampang baik, paling rapi serta aktif dalam urusan kelompok belajar. (2) Kemampuan pikir, antara lain: mempunyai inisiatif dalam belajar, banyak memikirkan kepentingan kelompok belajar, dan mengemukakan buah pikeran dalam belajar. (3) Sikap, sifat, dan perasaan, antara lain: bersikap sopan, dalam belajar, memperhatikan orang lain dalam belajar, penyabar dan dapat menahan dalam belajar. (4) Pribadi, meliputi: jujur pada saat belajar, dapat dipercaya, bertanggung jawab dan suka menjalankan pekerjaannya, menaati aturan kelompok belajar. (5) Aspek lain meliputi pemurah dan tidak pelit, suka bekerjasama dan membantu anggota kelompok belajar (Mappiere, 1982: 20).

\section{Pelaksanaan Bimbingan Pribadi Sosial di SMP Negeri 5 Banguntapan}

a. Persiapan

Proses bimbingan pribadi sosial yang dilakukan oleh guru BK dalam mengembangkan keterampilan sosial di SMP negeri 5 Banguntapan berdasarkan hasil wawancara dengan guru BK, maka 
dapat disimpulkan bahwa tahap persiapan ini terkait dengan beberapa hal berikut:

1) Menetapkan Personil

Dalam melaksanakan tugasnya, guru BK di SMP Negeri 5 Banguntapan tidak bekerja sendiri, terdapat beberapa personil yang turut andil dalam pelaksanaan bimbingan pribadi sosial. Guru BK melakukan kolaborasi antara guru BK dengan OSIS, guru piket, guru wali kelas dan juga kepala sekolah. Beberapa personil yang terlibat dalam membantu kinerja guru BK antara lain, OSIS yang turut andil memberikan input kepada guru BK saat orintasi awal selain itu juga kegiatan-kegiatan sekolah yang diselenggarakan oleh OSIS. Guru piket bertugas memberi input kaitannya saat siswa terlambat datang dan bolos sekolah. Guru wali kelas dan guru mata pelajaran memberi input terkait kondisi siswa saat proses pembelajaran. Koordinasi yang dilakukan oleh guru BK ini sangat efektif dilakukan, begitu pula dengan data yang diperoleh. Semakin banyak masukan, semakin banyak input semakin mudah bagi guru BK dalam menentukan kebijakan yang akan dilakukan (widayanti, 2013).

2) Assessment dan Identifikasi Siswa

Dalam kinerjanya, bimbingan yang dilakukan oleh guru Bk tidak terlepas dari namanya alat assessment. Alat assessment yang dibutuhkan dan dimiliki oleh guru BK di SMP Negeri 5 Banguntapan sebagai penunjang kinerjanya berupa catatan pribadi siswa, sosiometri, angket dan juga daftar cek masalah (DCM). Hal pertama yang dilakukan oleh guru BK setelah mendapatkan data dari alat assessment dan juga input dari personil pendukung persiapan layanan adalah mengidentifikasi catatan pribadi siswa, hasil sosiometri dan hasil DCM. Kemudian guru BK menganalisis data yang diperoleh (Sajini, 2013).

Pada tahap identifikasi implementasi pada tahap persiapan yang dilakukan oleh guru BK dalam menentukan sasaran bimbingan pribadi sosial yaitu dengan cara mengidentifikasi siswa yang bermasalah, kaitannya dalam hal ini adalah siswa terisolir. Perlunya identifikasi bagi siswa terisolir guna mengetahui permasalahan dan penyebab dari timbulnya masalah yang dihadapai oleh siswa. Dari 
identifikasi ini guru BK menentukan penanganan yang akan dilakukan setelah mengetahui sebab-sebab dari terisolirnya siswa di SMP Negeri 5 Banguntapan (Widayanti, 2013).

3) Kategorisasi Siswa Terisolir

Implementasi yang dilakukan pada tahap perencanaan guru BK di SMP Negeri 5 Banguntapan adalah dengan mengklasifikasikan siswa yang bermasalah khususnya bagi siswa terisolir dengan cara membedakan permasalahan berdasarkan tingkat masalah yang dialami oleh siswa yang bersangkutan. Dari data yang diperoleh pada tahun ajaran ini mengalami peningkatan dari tahun sebelumnya (Widayati, 2013).

b. Pelaksanaan

1) Menyusun Program

Program penanganan siswa terisolir ini disusun dengan beberapa hal terkait seperti memilih materi yang tepat, kemudian membentuk layanan dan kegiatan yang sesuai, mengatur jadwal pelaksanaan, kerjasama serta teknis dan strateginya. Untuk lebih jelasnya berikut ini gambaran susunan program:

Tabel. 1

Susunan Program Pengembangan Keterampilan Sosial Siswa Terisolir

\begin{tabular}{|c|l|l|}
\hline No. & Jenis Susunan Program & \multicolumn{1}{|c|}{ Keterangan } \\
\hline 1. & Materi & Jadwal materi \\
\hline 2. & Jadwal & Jam kosong dan istirahat \\
\hline 3. & Koordinasi personil & $\begin{array}{l}\text { Kepala Sekolah, Wali Kelas dan } \\
\text { Guru Mata Pelajaran }\end{array}$ \\
\hline 4. & Teknik dan strategi & $\begin{array}{l}\text { Satu paket dengan layanan dan } \\
\text { kegiatan pendukung }\end{array}$ \\
\hline
\end{tabular}

Berdasarkan tabel di atas, susunan program bimbingan pribadi sosial dalam mengembangkan keterampilan sosial siswa terisolir di SMP Negeri 5 Banguntapan dapat dijelaskan bahwa: 
1) Materi

Materi pengembangan keterampilan sosial secara keseluruhan dari masalah ke dalam program tahunan BK, baik untuk siswa terisolir maupun tidak. Materi ini merupakan bahan teoritis yang disesuaikan dan dibuat dalam bentuk modul oleh guru BK di SMP Negeri 5 Banguntapan. Materi ini disampaikan kepada seluruh siswa baik yang terindikasi memiliki masalah keterampilan sosial maupun mereka yang tidak terindikasi secara sosial.

Materi ini sudah menjadi satu paket dalam program BK yang tersusun selama satu tahun pelajaran sabagai bagian dari modul pengembangan diri siswa. Materi ini disajikan dalam layanan informasi dan pembelajaran. Layanan informasi dan pembelajaran adalah layanan yang berupa klasikal di kelas. Biasanya dilaksanakan ketika jam kosong, karena BK di SMP Negeri 5 Banguntapan tidak mendapatkan jam masuk kelas. Di samping itu, materi ini disisipkan pada layanan bimbingan kelompok dan konseling kelompok.

Layanan bimbingan kelompok dan konseling kelompok ini ditujukan kepada siswa-siswa yang bermasalah, termasuk siswa yang dianggap kurang mampu mengembangkan keterampilan sosialnya, sehingga mereka sangat membutuhkan materi ini. Adapun materi-materi yang terkait dengan pengembangan keterampilan sosial siswa tersebut antara lain sebagai berikut:

1) Kiat-kiat Komunikasi Efektif

2) Cara Meningkatkan Kemampuan Bekerjasama

3) Pentingnya Memiliki Sikap Tegas

4) Pentingnya Memiliki Tanggung Jawab

5) Pentingnya Memiliki Keterampilan Berempati

6) Kiat-kiat Bergaul dan Melibatkan diri dalam Kelompok

7) Cara Mengontrol Diri

Tujuan dibuat dan disampaikannya materi-materi tersebut adalah untuk membantu siswa yang bermasalah dengan keterampilan sosial. Secara umum untuk memperluas dan memperdalam kemampuan keterampilan sosial siswa yang tidak terindikasi atau tidak terisolir.

2) Jadwal 
Pengaturan jadwal pengembangan keterampilan sosial siswa dapat dikategorikan menjadi dua, insidental dan terprogram. Insidental berupa penggunaan jam kosong, sedangkan terprogram berupa kegiatan yang telah dijadwalkan dari sekolah misalnya ekstrakurikuler.

3) Personil

Personil pelaksana program yaitu melalui koordinasi antara guru BK dengan Kepala Sekolah, Wali Kelas dan guru mata pelajaran. Proses kerjasama tersebut selalu dilakukan agar terciptanya koordinasi yang baik sehingga program tersebut dapat terlaksana.

c. Implementasi Program Penanganan

Penanganan siswa terisolir dalam rangka mengembangkan keterampilan sosialnya dilakukan dengan berbagai teknik dan strategi. Teknik dan strategi ini ada yang dilakukan secara langsung maupun tidak langsung. Secara rinci dapat dijelaskan proses implementasinya, adalah sebagai berikut:

1) Melalui Layanan

Implementasi penanganan siswa dalam rangka mengembangkan keterampilan sosial siswa terisolir yang dilakukan dengan layanan antara lain melalui beberapa layanan, yaitu sebagai berikut:

a) Layanan Orientasi

Layanan orientasi bermaksud membantu siswa untuk mengenal dan memahami lingkugan atau situasi yang baru dimasukinya seperti sekolah baru, kelas baru dan semester baru, sehingga siswa lebih mudah dan lancar dalam menyesuaikan diri terhadap kehidupan sosial di lingkungan sekolahnya. Layanan orientasi ini diberikan sejak siswa pertama kali masuk sekolah yaitu pada saat masa orientasi siswa (MOS). Salah satu tujuan yang berkaitan dengan keterampilan sosial adalah agar siswa khususnya yang terisolir dapat menjadi pribadi yang mantap, mandiri serta mampu mengoptimalkan potensi yang dimiliki dan dapat bersosialisasi dengan baik, sehingga siswa tersebut dapat menjalankan kehidupannya seperti siswa yang lain (Widiyati, 2013). 
Bimbingan yang dimaksud siswa maupun guru BK di atas adalah salah satu bentuk bimbingan yang diberikan kepada siswa yang mendukung terbentuknya pibadi yang dinamis sehingga dapat menyesuaikan dengan lingkungan sekitar (Sajini, 2013).

Layanan orientasi yang dilakukan di SMP Negeri 5 Banguntapan dijadikan sebagai upaya dalam membantu siswa dalam mengembangkan keterampilan sosialnya, sehingga mampu melaksanakan tugas perkembangannya dengan baik yaitu masa transisi dari masa kanak-kanak ke remaja.

b) Layanan informasi

Layanan informasi merupakan layanan bimbingan dan konseling dalam membantu siswa dan orang tua serta pihak lain yang terkait untuk dapat menerima dan memahami informasi yang mereka perlukan untuk bahan membuat perencanaan atau pengambilan keputusan. Layanan informasi yang diberikan di SMP Negeri 5 Banguntapan berjalan secara terus menerus dan berkelanjutan yaitu mulai dari kelas VII hingga kelas IX.

Layanan informasi berkaitan dengan bimbingan pribadi sosial ini dilakukan oleh guru BK kepada siswa baru hingga menjadi siswa di sekolah tersebut. Materi terkait dengan keterampilan sosial yang pernah diberikan oleh guru BK antara lain komunikasi dengan teman sebaya, persahabatan, akhlak mulia dan memahami potensi diri. layanan ini bertujuan agar siswa dapat menjalani tugas-tugas perkembangan masa remaja, khususnya tentang keterampilan sosial dan perkembangan pribadi. Pada bagian ini, guru BK menjelaskan pentingnya mengembangkan keterampilan sosial dan mengoptimalkan potensi yang dimiliki. Dengan arahan tersebut diharapkan siswa khususnya yang terisolir dapat menjalani kehidupannya seperti siswa yang lain (Widiyati, 2013).

Berdasarkan pemaparan di atas menunjukan bahwa layanan informasi sangat perlu diberikan kepada siswa terisolir sehingga mendapatkan berbagai informasi mengenai hal-hal yang berkaitan dengan keterampilan sosialnya. Karena 
keterampilan sosial yang baik akan membantu siswa terisolir dapat diterima oleh teman dan linkungan sekitar.

c) Layanan pembelajaran

Layanan pembelajaran berupaya untuk membantu siswa mengembangkan sikap dan kebiasaan belajar yang baik, dapat mengikuti dan memperoleh manfaat yang optimal dari kegiatan belajar di sekolah, dan juga berguna bagi perkembangan siswa didik (Sajini, 2013).

Materi pembelajaran yang disampaikan oleh guru BK khusus untuk menangani siswa terisolir di atas adalah bentuk pembelajaran kepada siswa terisolir agar dapat menjadi pribadi yang mantap, mandiri serta mampu mengoptimalkan potensi yang dimiliki dan dapat bersosialisasi dengan baik, sehingga siswa tersebut dapat mejalankan kehidupannya seperti siswa yang lain.

d) Layanan penempatan dan penyaluran

Dalam pelaksanaannya, layanan penempatan dan penyaluran di SMP Negeri 5 Banguntapan disesuaikan dengan kebutuhan siswa itu sendiri. Praktiknya siswa yang terisolir di arahkan oleh guru BK untuk lebih diasah kembali kemampuan dan keterampilan sosialnya agar siswa tersebut tidak terisolir kembali.

Salah satu usaha yang dilakukan oleh guru BK di SMP Negeri 5 Banguntapan adalah dengan mengarahkan siswa agar lebih aktif untuk bersosialisasi dan diikutsertakan dalam setiap kegiatan sekolah seperti OSIS, ekstrakulikuler dan seminar pelatihan.

2) Kegiatan Pendukung

Adapun layanan pendukung dalam membantu pelaksanaan bimbingan keterampilan sosial siswa terisolir antara lain:

a) Aplikasi instrumentasi

Aplikasi instrumentasi di sini bermakna yaitu kesimpulan data yang diperoleh melalui pengukuran yang dilakukan dengan menggunakan alat ukur atau instrument tertentu. Alat ukur atau instrument yang digunakan dalam mengungkap kondisi sosial siswa melalui instrument non tes yaitu sosiometri. 
b) Himpunan data

Himpunan data diartikan suatu upaya untuk menghimpun dan memperoleh data tentang siswa, selanjutnya data akan dianalisis, ditafsirkan serta disimpan. Jenis data yang dihimpun sebelum melaksanakan bimbingan keterampilan sosial siswa terisolir juga mencakup data sosial seperti latar belakang keluarga siswa, status sosial siswa di sekolah dan lingkungan sosial siswa.

Selain hasil dari instrumentasi, data yang tercantum dalam himpunan data juga diperoleh dari buku atau kartu pribadi siswa dan observasi sehingga hal itu dapat dijadikan pertimbangan untuk memberikan bimbingan keterampilan bagi siswa terisolir.

c) Konferensi kasus

Konferensi kasus sangat penting untuk dilaksanakan. Melalui konferensi kasus, proses penyelesaian masalah siswa dilakukan tidak hanya mengandalkan pada guru BK di sekolah semata, tetapi bisa dilakukan secara kolaboratif, dengan melibatkan berbagai pihak yang dianggap kompeten dan memiliki kepentingan dengan permasalahan yang dihadapi siswa. Pihak-pihak tersebut antara lain seperti kepala sekolah, wali kelas dan wakil kesiswaan.

d) Kunjungan rumah (Home visit)

Kunjungan rumah bertujuan untuk memperoleh data tambahan tetang siswa. Selain itu juga untuk memperoleh dukungan dan kerja sama dari orang tua siswa dalam rangka mengentaskan masalah siswa. Kunjungan rumah ini dilakukan oleh guru BK saat pulang sekolah. Apabila orang tua sulit ditemui saat diadakannya kunjungan rumah, kegiatan ini bisa diganti dengan mengundang orang tua ke sekolah untuk membicarakan masalah siswa. Selama Tahun Ajaran 2013/2014 kunjungan rumah dilakukan pada kasus siswa yang terisolir.

e) Alih tangan kasus

Tidak semua masalah yang dialami siswa berada dalam kewenangan dan kemampuan guru BK namun untuk masalah keterampilan sosial bagi siswa terisolir guru BK 
menganggap masih dapat diselesaikan dengan bantuan personil pendukung yang dimiliki sekolah.

3) Kegiatan Penunjang

Kegiatan penunjang dalam rangka membantu siswa terisolir dalam mengembangkan keterampilan sosialnya yaitu melalui tiga kegiatan. Kegiatan tersebut antara lain sebagai berikut:

a) Ekstrakurikuler

Adanya kegiatan ektrakurikuler di SMP Negeri 5 Banguntapan setidaknya sangat membantu khususnya dalam hal pengembangan diri siswa terisolir yang dalam hal ini terkait pengembangan keterampilan sosialnya. Selebihnya juga berguna untuk mengembangkan potensi yang dimiliki oleh siswa yang memiliki kelebihan di bidang akademis, yaitu siswa yang dapat menyalurkan potensi berupa bakat yang dimiliki.

Adapun kegiatan ekstrakurikuler yang menjadi kegiatan pendukung dalam rangka mengembangkan keterampilan sosial siswa terisolir di SMP Negeri 5 Banguntapan di antaranya yaitu pramuka, basket, silat, karawitan dan pleton inti/baris berbaris.

\section{b) Outbond}

Kegiatan outbond dilakukan satu kali dalam satu tahun. Kegiatan ini merupakan program sekolah yang di dalamnya terdapat peran BK. Sekolah dan BK berkoordinasi dengan baik dalam melaksanakan program kegiatannya dengan tujuan agar siswa mendapatkan pelayanan terbaik di sekolah.

Kegiatan ini dilakukan di luar sekolah. Tujuan dari diadakannya outbond adalah sebagai salah satu cara untuk mengembangkan diri siswa. Dalam kegiatan tersebut banyak nilai positif yang dapat diambil di antaranya yaitu menumbuhkan kepercayaan diri siswa, meningkatkan kerjasama di dalam kelompok dan mengembangkan keterampilan sosial siswa. Keterampilan sosial siswa akan terbentuk ketika siswa tersebut mampu berkomunikasi 
efektif dengan temannya dan mampu bekerjasama dengan baik.

c) Seminar dan pelatihan

Seminar dan pelatihan sebagai kegiatan penunjang dalam pelaksanaan bimbingan di SMP Negeri 5 Banguntapan di implementasikan secara berkala dan berkesinambungan dua kali dalam setiap tahunnya.

Seminar dan pelatihan yang dilaksanakan dikemas dalam satu rangkaian kegiatan yang rutin dilaksanakan oleh pihak sekolah yaitu pada saat masa orientasi siswa baru (MOS) dan juga pada saat pembekalan dan pesantren menjelang ujian nasional untuk siswa kelas IX.

Inti yang ditekankan pada kegiatan di atas pada saat MOS adalah pengembangan keterampilan sosial siswa guna memudahkan siswa baru beradaptasi dengan lingkungan dan sosial yang baru. Selain itu juga pada saat pembekalan menjelang ujian akhir nasional, dengan tujuan siswa memiliki kepercayaan diri atas kemampuannya dan juga pembekalan mental untuk siswa tersebut.

d. Evaluasi Hasil Pelaksanaan

Evaluasi yang digunakan dalam tahap ini yaitu evaluasi jangka pendek dan evaluasi jangka panjang. Evaluasi jangka pendek dilakukan setelah berakhirnya proses bimbingan pribadi sosial baik konseling individu maupun bimbingan kelompok dalam waktu beberapa hari atau beberapa minggu bahkan bulan setelah bimbingan berlangsung. Sedangkan evaluasi jangka panjang yang dilakukan guru BK yaitu dengan melakukan pemantauan perkembangan siswa secara signifikan melalui guru mata pelajaran dan wali kelas siswa (Widayati, 2013).

Dapat diketahui bahwa guru BK ikut berperan aktif dalam melakukan observasi langsung kepada siswa yang telah mengikuti bimbingan pribadi sosial, dengan cara menggali informasi mengenai siswa tersebut melalui guru mata pelajaran dan wali kelas selaku guru yang bertanggung jawab terhadap segala sesuatu yang ada di kelasnya.

Evaluasi yang dilaksanakan dalam pelaksanaan bimbingan ini dilakukan setelah melihat hasil bimbingan guru BK terhadap siswa terisolir. Kaitannya dalam hal ini adalah kondisi siswa sebelum dan sesudah mendapatkan bimbingan. 
Dari data yang diperoleh di lapangan diketahui sebanyak 21 siswa memiliki keterampilan sosial yang rendah dan terisolir. Sebanyak 5 siswa terisolir tersebut dikategorikan ke dalam kategori berat dan 16 sisanya dikategorikan ringan. Kategori yang digunakan didasarkan atas keterampilan siswa yang kurang dan juga faktor pendukung yang membuat siswa tersebut terisolir.

Bimbingan pribadi sosial dalam hal pengembangan keterampilan sosial yang dilakukan oleh guru BK di SMP Negeri 5 Banguntapan khususnya bagi siswa yang memiliki kriteria berat dalam keterampilan sosialnya dapat dikatakan berhasil, berikut petikan siswa yang telah mendapatkan bimbingan dari guru BK.

Bimbingan konseling di SMP Negeri 5 Banguntapan menunjukkan bahwa siswa terisolir yang mengikuti layanan bimbingan pribadi sosial yang berkaitan dengan keterampilan sosial siswa berhasil dikembangkan dengan berbagai jenis layanan yang membuat siswa lebih percaya diri, mudah diterima oleh teman-temannya dan pandai berkomunikasi, sehingga siswa terisolir tersebut mampu menjalani kehidupan yang dinamis sesuai kewajibannya sebagai remaja serta dari beberapa metode bimbingan pribadi sosial yang telah berjalan secara langsung siswa mampu memecahkan permasalahan yang dihadapinya dengan arahan dari guru BK.

e. Tindak Lanjut Hasil Pelaksanaan

Walaupun proses konseling sudah selesai dan sudah menemukan solusi dalam penyelesaian masalahnya, tugas guru BK selanjutnya adalah mengadakan tindak lanjut dari hasil bimbingan pribadi sosial untuk siswa terisolir. Bentuk tindak lanjut yang diterapkan oleh guru BK yaitu melakukan pengamatan dan pengawasan secara langsung atau sembunyisembunyi.

Selain itu jika dalam menyelesaiakan masalah tersebut perlu adanya campur tangan dari orangtua, maka orangtua akan dipanggil untuk ke sekolah guna menemui guru BK yang bersangkutan dan secara langsung orangtua akan dilibatkan pula dalam menyelesaikan masalah siswa tersebut. Intinya orangtua dan guru BK bekerja sama dalam memantau perkembangan siswa kedepannya. Jika siswa menunjukkan perkembangan yang baik dalam artian siswa sudah terbebas dari permasalahan dengan lingkungan sosialnya maka siswa tersebut hanya cukup dipantau sedangkan siswa yang masih menunjukkan tanda-tanda 
bermasalah dan belum ada perubahan setelah mengikuti bimbingan pribadi sosial sebelumnya maka guru BK merencanakan kembali bimbingan guna mengasah keterampilan sosial bagi siswa terisolir (Widayati, 2013).

\section{Simpulan}

Pelaksanaan bimbingan pribadi sosial dalam mengembangkan keterampilan sosial siswa terisolir di SMP Negeri 5 Banguntapan dilaksanakan dengan beberapa tahapan yaitu 1) Persiapan meliputi menentukan personil, alat assessment dan identifikasi siswa juga kategori siswa terisolir 2) Pelaksanaan meliputi menyusun program dan implementasi program penanganan 3) Evaluasi hasil pelaksanaan dan 4) Tindak lanjut hasil pelaksanaan. 


\section{DAFTAR PUSTAKA}

Ahmadi, A., \& Rohani, A. (1991). Bimbingan dan konseling di sekolah. Retrieved from https://books.google.co.id/books?id=kh6TngEACAAJ

Anggraeni, S. (2008). Pengaruh Pelatihan Keterampilan Sosial Menggunakan Metode Stop Think Do terhadap Penyesuaian Sosial Anak Sekolah Dasar. Manasa, 2 No. 1.

Burhanudin, Y. (1999). Kesehatan Mental. Bandung: Pustaka Setia.

Depag RI. (2010). Al-Qur'an dan Tafsirnya. Jakarta: Lentera Abadi.

Enjang AS. (2001). Komunikasi Konseling, Dari Wawancara, Seni Mendengar, Sampai Soal Kepribadian. Bandung: Penerbit Nuansa.

Faqih, A. R. (2001). Bimbingan dan Konseling dalam Islam. Yogyakarta: UII Press.

Hurlock, E. B. (1990). Perkembangan Anak (6th ed.). Jakarta: Erlangga.

Kelly, J. A. (1982). Social Skill Training: A Practical Guide for Interventions. New York: Spinger Publishing.

Knoers, F. J. M., A. M. P., \& Haditono, S. R. (2004). Psikologi Perkembangan. Yogyakarta: Gadjah Mada University Press.

Latipun. (2001). Psikologi Konseling. Malang: UNM Press.

Mappiere, A. (1982). Pengantar Bimbingan dan Konseling di Sekolah. Surabaya: Usaha Nasional.

Masturi. (2015). Counselor Encapsulation:"Sebuah Tantangan dalam Pelayanan Konseling Lintas Budaya”, (No. 2). Jurnal Konseling GUSJIGANG.

Petersen, L. R. (2004). Bagaimana Memotivasi Anak Belajar: Stop and Think Learning (I. Isdito, trans.). Jakarta: Gramedia Pustaka Utama.

Rahman, H. S. (2003). Bimbingan dan Konseling Pola 17. Yogyakarta: UCY Press.

Robert L. Gibson. (2011). Bimbingan dan Konseling. Yogyakarta: Pustaka Pelajar.

Safira, T. (2005). Interpersonal Intelligence. Yogyakarta: Asmara Books.

Siswati, N. (2010). Pengaruh Social Stories terhadap Keterampilan Sosial Anak dengan Attention-Defisit Hyperactivity Disorder. Jurnal Psikologi Undip, 8 (2).

Sukardi, D. K. (1993). Organisasi Administrasi di Sekolah. Surabaya: Usaha Nasional.

Tohirin. (2017). Bimbingan dan Konseling di Sekolah dan Madrasah (Berbasis Integrasi). Jakarta: Raja Grafindo Persada.

Walgito, B. (1989). Bimbingan dan Penyuluhan di Sekolah. Yogyakarta: Andi Offset.

Walgito, B. (2004). Bimbingan dan Konseling Studi dan Karir. Yogyakarta: Andi Offset.

Yusuf, S. (2006). Psikologi Perkembangan Anak dan Remaja. Bandung: Remaja Rosdakarya.

Zikra, W. A. I. (2013). Karakteristik Belajar Siswa Terisolir. Jurnal Ilmiah Konseling UNP, 2 No. 1.

Johnson \& Johnson, 1989, Social Skill, http://www.psychologymania.com/2012/12/hasil penting dari memiliki keterampilan sosial.html. Diakses 30 Agustus 2013. 
Keterampilan sosial. http://vidaiponk.blogspot.com/2012/05/keterampilan-sosialkerjasama.html, diakses tanggal 8 Juli 2013

$\begin{array}{lllll}\text { Stephen N. } & \text { Elliott, } & \text { Social }\end{array}$ http://www.psychologymania.com/2012/12/karakteristik-siswa-yang-memilikiketerampilan-sosial.html. Diakses 8 Juli 2013.

Eisler dalam L'Abate dan Milan, 1985, Social Skill, http://www.psychologymania.com/2012/12/karakteristik-siswa-yang-memilikiketerampilan-sosial.html. Diakses 12 Juli 2013.

Wawancara dengan Ibu Eni Widayati, pada tanggal 14 November 2013, di ruang BK.

Wawancara dengan Ibu Sajini, pada tanggal 12 November 2013, di ruang BK. 